\title{
PENGELOLAAN SUMBER DAYA IKAN BILIH (Mystacoleucus padangensis Blkr) ENDEMIK BERBASIS KEARIFAN LOKAL DI DANAU SINGKARAK
}

\author{
Hafrijal Syandri' ${ }^{\text {; Junaidi }}{ }^{1}$ dan Azrita ${ }^{2}$ \\ 1) Dosen pada Fakultas Perikanan dan IImu Kelautan Universitas Bung Hatta Padang \\ 2) Dosen pada Fakultas Keguruan dan Ilmu Pendidikan Universitas Bung Hatta Padang \\ Teregistrasi I tanggal: 27 Mei 2011; Diterima setelah perbaikan tanggal: 18 Agustus 2011; \\ Disetujui terbit tanggal: 29 September 2011
}

\begin{abstract}
ABSTRAK
Pesatnya kegiatan penangkapan ikan bilih endemik di Danau Singkarak, sudah mengindikasikan penurunan populasi dan ukuran ikan tersebut. Oleh karena itu perlu dikelola agar dapat dimanfaatkan secara berkelanjutan. Salah satu alternatif pengelolaannya adalah berbasis kearifan lokal. Untuk itu diperlukan kebijakan pengelolaan ikan bilih berbasis kearifan lokal yang ada pada masyarakat nelayan. berdasarkan analisis SWOT dari sembilan strategi yang diperoleh, maka tiga strategi yang menjadi prioritas utama pengelolaan ikan bilih yaitu (1) pengelolaan penangkapan ikan berbasis kearifan lokal dengan nilai manfaat 0,518, (2) pengelolaan habitat ikan melalui pembuatan reservat secara ko-manajemen dengan nilai manfaat 0,280 dan (3) pengelolaan populasi ikan melalui pembenihan dan restoking dengan nilai manfaat 0,202 . Peraturan yang lebih baik dalam pengelolaan dan pelestarian ikan bilih adalah dengan hukum adat dengan nilai manfaat 0,095 .
\end{abstract}

\section{KATAKUNCI : ikan bilih, pengelolaan dan kearifan lokal}

ABSTRACT : Management of endemic bilih fish resources (Mystacoleucus padangensis Blkr) based on local wisdom in Singkarak Lake By: Hafrijal Syandri, Junaidi and Azrita

Overfishing of bilih fish endemic in Singkarak lake indicated a decrease in population and size of the fish. Therefore, it is necessary to do a management in order a sustainable. One of the alternative management is based on local wisdom. The aim of this research was to determine of management priorities based on local wisdom that exist in the fish communities. From the research finding it can be explained that among the nine strategies which were obtained from the SWOT analysis, then the three strategies of the top priority of the management of bilih fish are (1) the management of fishing based on local wisdom with advantage value of 0.518 , (2) management of fish habitat through the creation of reserves comanagement with a advantages value of 0.280 and (3) management of fish populations through hatchery and restocking with advantage value of 0.202 . The better regulation in management and conservation bilih fish by customary law with adventages value of 0,095 .

KEYWORDS : bilih fish, management and local wisdom 


\section{PENDAHULUAN}

Sumber daya ikan perairan umum daratan berperan penting sebagai sumber protein dan ketahanan pangan, sumber ekonomi masyarakat, sumber lapangan kerja, sumber plasma nutfah dan sumber devisa dan pendapatan asli daerah (Kartamihardja et al., 2009). Salah satu sumber daya perikanan di Danau Singkarak adalah ikan bilih bersifat endemik (Weber dan Beaufort, 1916; Kottelat et al., 1992) dan bernilai ekonomis (Syandri, 1996). Penangkapan dilakukan setiap hari dengan sistim alahan (54 unit), jaring insang (854 unit), bubu (60 unit), jala (250 unit), bahan peledak dan setrom dengan produksi sekitar 2,0 ton per hari (Syandri, et al., 2008), dominan populasi ikan yang tertangkap sedang bertelur (Syandri, 2011). Hasilnya selain dikonsumsi secara lokal, juga dipasarkan ke Propinsi Riau, Jambi, Sumatera Utara dan Kepulauan Riau, termasuk ke Malaysia dalam bentuk ikan olahan dengan harga ikan segar Rp 30.000,$/ \mathrm{kg}$ dan olahan Rp70.000,-/kg (Syandri, 2008)

Ukuran populasi ikan bilih Danau Singkarak saat sekarang berkisar $6-7$ $\mathrm{cm}$ (Syandri, 2011) lebih kecil jika dibandingkan dengan ukuran tahun 1996 berkisar 10-14 cm (Syandri, 1996), sedangkan ukuran ikan bilih yang berasal dari Danau Toba berkisar $11,5-14,5 \mathrm{~cm}$ (Kartamihardja, 2009). Berdasarkan data tersebut maka populasi ikan bilih di Danau Singkarak terancam punah. Ancaman kepunahan sumber daya ikan bilih antara lain disebabkan oleh : (1) penangkapan yang tidak terkendali dengan berbagai jenis alat tangkap, (2) ikan yang ditangkap di beberapa muara sungai yang sedang beruaya ke daerah pemijahan dominan sedang mengandung telur, (3) perubahan kualitas air akibat bendungan PLTA Singkarak, (4) ketergantungan masyarakat nelayan terhadap ikan bilih sangat dominan dan (5) belum ada kawasan konservasi ikan bilih berbasis masyarakat (Syandri, 2008). Oleh sebab itu, ikan bilih penting dilestarikan melalui pengelolaan penangkapan, habitat dan populasi berdasarkan kearifan lokal dengan melibatkan pemangku kepentingan. Tulisan ini bertujuan membahas tentang peluang, ancaman, kekuatan dan kelemahan dan strategi pilihan dalam kebijakan pengelolaan plasma nutfah ikan bilih di Danau Singkarak sebagai dasar untuk melakukan pengelolaan berbasis masyarakat, ramah lingkungan dan bernilai ekonomis.

\section{STRATEGI PENGELOLAAN IKAN BILIH BERDASARKAN ANALISIS SWOT.}

Berdasarkan pendekatan analisis SWOT faktor strategis eksternal berupa peluang dan ancaman dan faktor strategis internal berupa kekuatan dan kelemahan, maka dari hasil pembobotan dan rangking dapat diketahui urutan tingkat kepentingan faktor-faktor tersebut, baik strategis internal maupun strategis eksternal seperti pada tabel EFAS (External Strategic Factors Analysis Summary) dan kotak IFAS (Internal Strategic Factors Analysis Summary).

Dari segi peluang dalam pengelolaan ikan bilih didukung oleh adanya potensi ikan bilih di Danau Singkarak, terbukanya pangsa pasar untuk ikan bilih segar maupun ikan olahan baik lokal maupun untuk ekspor dan komoditi ikan bilih merupakan penghasilan utama bagi nelayan serta dapat menyerap tenaga kerja. Dari sisi ancaman pengelolaan dan pelestarian ikan bilih, faktor terpenting yang harus diperhatikan adalah penangkapan ikan bilih saat sekarang masih ada yang dilakukan dengan menggunakan alat tangkap yang tidak ramah lingkungan yaitu bahan peledak, strom, adanya kecenderungan 
bertambahnya alat tangkap jaring insang (panjang 100 meter dan tinggi 2,5 meter) dengan mata jaring kecil (3/4 inci) dan berkurangnya jumlah jaring insang dengan luas mata jaring 1,0 inci sehingga ikan yang tertangkap lebih dominan sedang bertelur serta bertambahnya jumlah nelayan. Di Danau Toba ikan bilih hanya boleh ditangkap dengan jaring insang dengan ukuran mata jaring 1,25 inci dan 1,50 inci sehingga ukuran ikan yang tertangkap berkisar antara 15,0 - 18,5 cm (Kartamihardja, 2009).

Dari sisi kekuatan dalam pengelolaan ikan bilih adalah awalnya ikan bilih hanya ada di Danau Singkarak, namun saat sekarang sudah berkembangbiak dan diproduksi dari Danau Toba (Kartamihardja, 2009). Ikan bilih mempunyai sifat reproduksi yang tinggi sepanjang tahun, bernilai ekonomi tinggi dan merupakan sumber mata pencaharian bagi nelayan. Dari sisi kelemahan adalah belum ada peraturan secara terpadu antar desa yang berada selingkar Danau Singkarak meliputi Kabupaten Tanah Datar dan Kabupaten Solok untuk pengelolaan ikan bilih, nelayan belum menyadari pentingnya pelestarian ikan bilih, rendahnya tingkat pendidikan nelayan yaitu 61,67\% berpedidikan tidak tamat dan tamat Sekolah Dasar serta belum adanya peran pemuka masyarakat dalam pelestarian ikan bilih.

Dari hasil identifikasi faktor eksternal (peluang dan ancaman) dan faktor internal (kekuatan dan kelemahan) di atas dapat disusun matrik SWOT yang menjadi arahan penyusunan strategi pengelolaan dan pelestarian ikan bilih di Danau Singkarak seperti ditampilkan pada Tabel 1. Dari hasil analisis EFAS dan IFAS dapat diketahui elemen-elemen kekuatan, kelemahan, peluang dan ancaman, sehingga selanjutnya dapat disusun rencana strategis dari keempat strategi di atas seperti yang tertera pada Tabel 2.

Kebijakan dan strategi pengelolaan ikan bilih Danau Singkarak berdasarkan skala perioritas yang ditampilkan pada Tabel 2 adalah sebagai berikut : (1) melakukan pengelolaan penangkapan ikan bilih berbasis kearifan lokal dengan nilai bobot 2,52; (2) melakukan pengelolaan habitat secara ko-manajemen dengan nilai bobot 2,11 ; (3) melakukan pengelolaan populasi ikan dengan nilai bobot 1,83; (4) meningkatkan produksi sesuai potensi ikan bilih yang ada dengan nilai bobot 1,62; (5) melakukan pengawasan dalam penangkapan ikan bilih dengan bobot 1,59; (6) penyuluhan kepada masyarakat akan pentingnya pelestarian ikan bilih dengan bobot 1,52; (7) membuat produk ikan bilih yang beragam dan memperluas pasar yang sudah ada dengan bobot 1,41 ; (8) tingginya permintaan pasar harus diikuti dengan diversivikasi produk yang bermutu dengan nilai bobot 1,35; (9) menentukan tata ruang sumberdaya ikan bilih di Danau Singkarak dengan bobot 1,33.

Dari sembilan strategi yang diperoleh dari hasil analisis SWOT, maka tiga strategi yang menjadi prioritas utama adalah (1) pengelolaan penangkapan ikan berbasis kearifan lokal, (2) pengelolaan habitat ikan melalui pembuatan reservat secara komanajemen dan (3) pengelolaan populasi ikan melalui pembenihan dan restoking . Strategis ini sejalan dengan rekomendasi pengelolaan sumber daya ikan di Danau Limbodo, Gorontolo yaitu rehabilitasi habitat, penentuan tata ruang, revitalisasi Peraturan Daerah Kabupaten Gorontolo mengenai pelarangan penggunaan alat tangkap dan revitalisasi kelembagaan nelayan (Krismono dan Kartamihardja, 2010). 
Tabel 1. EFAS dan IFAS Pengelolaan dan Pelestarian Ikan Bilih Danau Singkarak

Table 1. EFAS and IFAS Management and conservation Bilih fish in Singkarak Lake

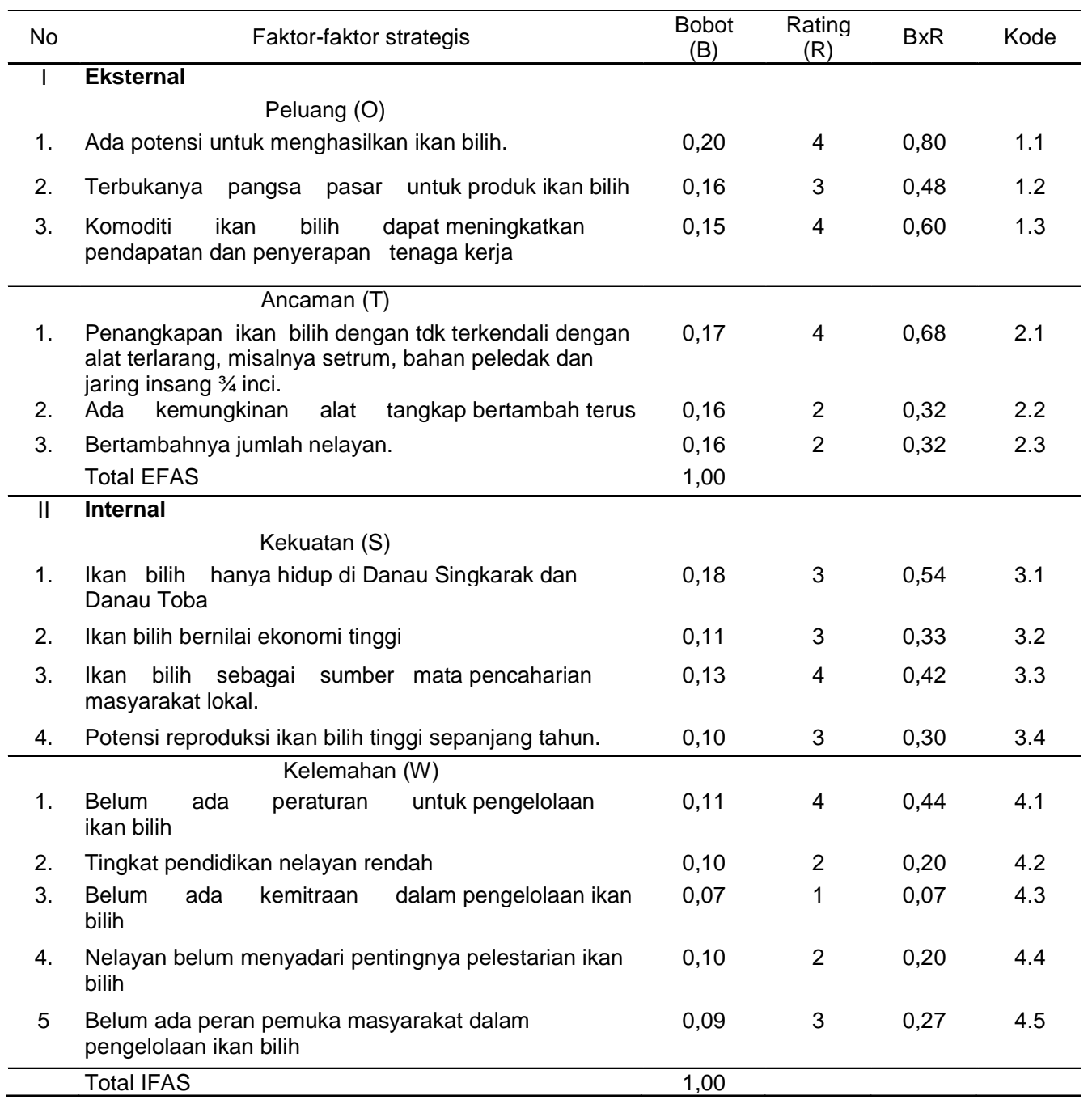


Tabel 2. Alternatif Strategi Dalam Pengelolaan dan Pelestarian Ikan Bilih Danau Singkarak.

Table 2. Strategic alternative on management and conservation bilih fish in

\begin{tabular}{|c|c|c|c|c|}
\hline No & Strategi & Bobot faktor strategis & $\begin{array}{r}\text { Total } \\
\text { bobot }\end{array}$ & Prioritas \\
\hline \multirow[t]{5}{*}{$\mathrm{I}}$. & S-0 & & & \\
\hline & $\begin{array}{l}\text { 1. Meningkatkan produksi sesuai potensi } \\
\text { ikan bilih yang ada }\end{array}$ & $0,48+0,60+0,54$ & 1,62 & IV \\
\hline & 2. Membuat produk ikan bilih yang beragam & $0,48+0,60+0,33$ & & \\
\hline & $\begin{array}{l}\text { dan memperluas pasar yang sudah ada. } \\
\text { 3. Melakukan pengelolaan penangkapan }\end{array}$ & & 1,41 & VI \\
\hline & berdasarkan kearifan lokal & $\begin{array}{c}0,80+0,48+0,6+0,54+0,4 \\
2\end{array}$ & 2,52 & I \\
\hline \multirow{3}{*}{ II. } & S-T & & & VI \\
\hline & 1. Penyuluhan kepada masyarakat & $0,68+0,54+0,30$ & 1,52 & $\mathrm{VI}$ \\
\hline & $\begin{array}{l}\text { pentingnya pelestarian ikan bilih. } \\
\text { 2. Menentukan tata ruang sumberdaya } \\
\text { perikanan danau Singkarak. }\end{array}$ & $0,68+0,32+0,33$ & 1,33 & IX \\
\hline \multirow[t]{3}{*}{ III } & W-O & & & \\
\hline & $\begin{array}{l}\text { 1. Melakukan pengelolaan habitat ikan } \\
\text { berdasarkan kearifan lokal }\end{array}$ & $\begin{array}{c}0,80+0,44+0,07+ \\
0,20+0,6\end{array}$ & 2,11 & II \\
\hline & $\begin{array}{l}\text { 2. Tingginya permintaan pasar harus diikuti } \\
\text { dengan diversifikasi produk yang bermutu. }\end{array}$ & $0,8+0,48+0,07$ & 1,35 & VIII \\
\hline \multirow[t]{3}{*}{ IV } & W-T & & & \\
\hline & $\begin{array}{l}\text { 1. Melakukan pengelolaan populasi ikan } \\
\text { bilih. }\end{array}$ & $\begin{array}{c}0,68+0,32+0,32+0,44+ \\
0,07\end{array}$ & 1,83 & III \\
\hline & $\begin{array}{l}\text { 2. Melakukan pengawasan penangkapan } \\
\text { bersama masyarakat }\end{array}$ & $0,68+0,44+0,20+0,27$ & 1,59 & V \\
\hline
\end{tabular}

STRATEGIS PENGELOLAN IKAN BILIH BERDASARKAN TINGKATAN PILIHAN (ANALYSIS HIERARCHY PROCESS, AHP)

Dari hasil analisis data dengan menggunakan AHP didapatkan bahwa pengelolaan dan pelestarian ikan bilih di Danau Singkarak harus lebih banyak memberikan manfaat ekonomis kepada masyarakat disekeliling danau dengan bobot 0,518 . Pendapat ini sangat sejalan dengan salah satu dimensi dan konsep pembangunan yang berkelanjutan dan berhasil guna dalam peningkatan kesejahteraan masyarakat, dimana masyarakat disekeliling danau yang seharusnya lebih awal menerima manfaat dari kegiatan apa saja yang ada di danau, karena masyarakat sekitar dan terdekat pulalah yang akan lebih dahulu menerima segala dampak dari kegiatan-kegiatan pembangunan yang dilaksanakan. (baik dampak positif maupun dampak negatif). Manfaat selanjutya adalah untuk kelestarian lingkungan dengan bobot 0,203; selanjutnya manfaat pengelolaan dan pelestarian ikan bilih harus memiliki dampak penguatan hukum dan kelembagaan dengan bobot 0,144 dan diakhiri dengan manfaat terhadap lingkungan sosial dengan bobot 0,211. Dari analisis data maka masing-masing elemen dalam manfaat pengelolaan dan pelestarian ikan bilih yang ada di Danau Singkarak ditinjau dari beberap aspek di bawah ini.

\section{Manfaat Ekonomi}

Ditinjau dari aspek ekonomi manfaat dari pengelolaan dan pelestarian ikan bilih ini adalah : (a) peningkatan pendapatan nelayan dengan bobot 0,281 ; dimana 
dengan dikelolanya pemanfaatan ikan bilih secara baik, jelas keberadaan ikan bilih di Danau Singkarak akan dapat dipertahankan dan dikendalikan, sehingga dapat dimanfaatkan oleh nelayan secara berkesinambungan. (b) meningkatnya usaha pengolahan dengan bobot 0,046; hal ini akan jelas bila produksi ikan bilih sepanjang waktu akan meningkatkan usaha disektor informal, antara lain dengan adanya pedagang/pengolah yang menjual produk ikan bilih siap saji dan lain sebagainya. (c) meningkatnya usaha disektor informal dengan bobot 0,114

\section{Manfaat Lingkungan}

Dari segi lingkungan manfaat pengelolaan ikan bilih ini adalah pertama dapat dipertahankan keberadaan ikan bilih (pelestarian ikan bilih yang ada di Danau Singkarak dengan bobot 0,102 dan yang kedua adalah terjadinya keseimbangan ekosistem dengan bobot 0,102), sehingga sumberdaya ikan bilih yang ada di Danau Singkarak dapat dimanfaatkan secara berkelanjutan bagi generasi sekarang dan generasi yang akan datang.

\section{Manfaat Sosial}

Ditinjau dari segi sosial manfaat pengelolaan dan pelestarian ikan bilih adalah dapat penyerapan tenaga kerja dengan bobot 0,176, dimana dengan adanya produksi ikan bilih sepanjang waktu jelas akan dapat menyerap tenaga kerja yang lebih banyak dan yang kedua adalah dapat mengurangi potensi konflik dengan bobot 0,035 .

\section{Manfaat Hukum dan Kelembagaan}

Hukum dan lembaga yang ada akan lebih bermanfaat dalam pengelolaan dan pelestarian ikan bilih ini, baik hukum/ peraturan pemerintah propinsi dengan bobot
0,030 dan pemerintah kabupaten dengan bobot 0,019 , dan akan lebih bermanfaat lagi dengan hukum adat (peraturan Nagari) dengan bobot 0,095.

\section{Kerugian pengelolaan dan pelestarian ikan bilih}

\section{Kerugian ekonomi}

Dari segi ekonomi dengan bobot 0,517, kerugian yang diperkirakan akan timbul dengan pengelolaan dan pelestarian ikan bilih adalah, pertama butuh modal $(0,245)$, kedua penurunan populasi ikan dengan bobot 0,194 dan yang ketiga butuh biaya pemeliharaan dengan bobot 0,077

\section{Kerugian Lingkungan}

Di pandang dari sudut lingkungan dengan bobot 0,142 ; kerugian akibat pengelolaan dan pelestarian ikan bilih adalah memungkinkan timbulnya pencemaran dengan bobot 0,028 dan kemungkinan penangkapan ikan dengan alat terlarang, misalnya bahan peledak dan setrum dengan bobot 0,114

\section{Kerugian Sosial}

Kerugian dari segi sosial dengan bobot 0,260 adalah ada kemungkinan kesempatan kerja yang hilang dengan bobot 0,195 karena dengan pengelolaan dan pelestarian ikan bilih, akan ada beberapa jenis alat tangkap yang tidak diperbolehkan beroperasi di danau Singkarak disamping itu juga terhadap perubahan gaya hidup dengan bobot 0,065

\section{Kerugian Hukum dan Kelembagaan}

Dari segi hukum dan kelembagaan dengan bobot 0,081 kerugian yang akan dirasakan adalah bertambahnya biaya operasional lembaga hukum dengan bobot 
0,020 dan keterbatasan ruang gerak masyarakat dengan bobot 0,061 karena adanya hukum yang mengatur.

\section{ALTERNATIF PENGELOLAAN IKAN BILIH}

Untuk mendapatkan alternatif yang optimal dalam pengelolaan dan pelestarian ikan bilih di Danau Singkarak, maka berdasarkan pernyataan para pemangku kepentingan, melalui perhitungan AHP dalam kerangka manfaat dan biaya untuk 3 (tiga) alternatif dalam strategi pengelolaan ikan bilih di Danau Singkarak, diperioritaskan untuk lebih memilih pengelolaan penangkapan dan pengelolaan habitat ikan seperti disajikan pada Tabel 3 . Pengelolaan sumberdaya ikan di suatu perairan harus dilakukan secara terintegrasi dan tidak saling tumpang tindih (Amis et al., 2009). Pengelolaan tersebut dapat mengikutsertakan aspek ilmu ekonomi, antropologi, hukum dan politik serta limnologi (Nasution dan Sunarno, 2009)
Dari hasil analisis tersebut di atas dapat dilihat bahwa alternatif pengelolaan penangkapan ikan memberikan nilai manfaat yang terbesar yaitu 0,518 , diikuti oleh alternatif pengelolaan habitat ikan dengan nilai manfaat 0,280 . Sedangkan alternatif pengelolaan populasi ikan memberikan nilai kerugian yang terbesar yaitu 0,493 . Namun demikian jika masingmasing alternatif dibandingkan antara nilai manfaat dan kerugian, maka alternatif pengelolaan penangkapan ikan memberikan nilai terbesar yaitu 2,643 . Alternatif ini menghasilkan strategi yang optimal karena merupakan nilai maksimum, dengan nilai $B / C>1$. Sedangkan untuk alternatif pengelolaan habitat nilai $\mathrm{B} / \mathrm{C}$ nya 0,900 seperti ditampilkan pada Tabel 3. Penggelolaan habitat dengan daerah suaka konservasi memberikan nilai terbaik untuk melestarikan ikan di Lubuk Lampam jika dibandingkan dengan perairan Lebak Petai yang tidak mempunyai suaka (Utomo et al., 2001)

Tabel 3. Alternatif pengelolaan ikan bilih berdasarkan nilai manfaat dan kerugian

Table 3. Alternative management bilih fish based value of the advantages and disadvantages

\begin{tabular}{lccc}
\hline \multirow{1}{*}{ Alternatif } & \multicolumn{2}{c}{ AHP } & \multirow{2}{*}{ Rasio Perbandingan } \\
\cline { 2 - 3 } & Manfaat & Kerugian & \\
\hline $\begin{array}{l}\text { Pengelolaan penangkapan ikan } \\
\text { berbasis kearifan lokal }\end{array}$ & 0,518 & 0,196 & 2,643 \\
$\begin{array}{l}\text { Pengelolaan habitat berbasis kearifan } \\
\text { lokal dan ko-manajeman }\end{array}$ & 0,280 & 0,311 & 0,900 \\
$\begin{array}{l}\text { Pengelolaan populasi ikan melalui } \\
\text { pembenihan dan restoking }\end{array}$ & 0,202 & 0,493 & 0,409 \\
\hline
\end{tabular}

Kemudian dari segi hukum dan kelembagaan bobot yang tertinggi adalah dengan hukum adat $(0,095)$ yang diikuti oleh hukum Pemerintah Propinsi Sumatera Barat $(0,030)$ dan hukum Pemerintah
Kabupaten Tanah Datar dan Kabupaten Solok ( 0,019). Hal ini berarti hukum adat lebih ditaati oleh masyarakat di selingkar danau dibandingkan dengan hukum 
pemerintah propinsi dan hukum pemerintah kabupaten untuk melestarikan ikan bilih.

Dengan demikian, dari hasil analisis AHP ini, ada dua alternatif strategi pengelolaan ikan bilih di Danau Singkarak yaitu (1) pengelolaan penangkapan ikan berbasis kearifan lokal dan (2) pengelolaan habitat ikan bilih berbasis kearifan lokal. Strategi yang digunakan dalam pengelolaan penangkapan ikan berbasis kearifan lokal adalah :

1) Menguatkan peraturan-peraturan penangkapan ikan yang telah berlaku di tengah-tengah masyarakat nelayan antara lain (1) masyarakat dilarang menangkap ikan dengan strom, bahan peledak, pukek dan jaring turiek, (2) dilarang menjala dari pukul 16.30 - 18.30 WIB dan pukul 02.00 - 03.00 WIB di muara-muara sungai karena ikan bilih akan bertelur; (3) dilarang memakai jaring bilih lebih dari satu banta $(90 \mathrm{~cm})$ tingginya dan setiap orang tidak boleh mengoperasikan jaring bilih lebih dari dua unit; (4) menangkap ikan di alahan hanya diperbolehkan dari pukul 04.00 06.00 WIB; (5) jaring bilih boleh dipasang dari muara sungai berjarak 50 $\mathrm{m}$ ke utara dan ke selatan dan $200 \mathrm{~m}$ ke arah tengah danau. Khusus untuk nagari (Desa) Sumpur tidak diperbolehkan mengoperasikan jaring bilih di perairan nagari tersebut.

2) Melakukan sosialisasi kepada masyarakat dan nelayan akan pentingnya pelestarian ikan bilih dan aturau-aturan serta langkah-langkah pengelolaan penangkapan ikan yang dibuat sehingga meningkatkan kesadaran masyarakat dan nelayan untuk ikut bersama-sama melakukan pengelolaan perikanan Danau Singkarak, yang akhirnya akan menjadikan pengelolaan yang berbasis masyarakat yang sesuai dengan kaidahkaidah lingkungan.

3) Strategi yang digunakan dalam pengelolaan habitat adalah menetapkan zonasi pemanfaatan danau berdasarkan kearifan lokal yang terdiri dari zona inti (suaka), zona penyanga (buffer zone), dan zona usaha (economic zone) .

\section{KESIMPULAN DAN REKOMENDASI}

1. Alternatif pengelolaan ikan bilih yang paling diperioritaskan secara berurutan adalah (1). pengelolaan penangkapan ikan berbasis kearifan lokal karena memperoleh bobot nilai manfaat terbesar yaitu 0,518 dan nilai bobot kerugian/ biaya 0,196 . (2) pengelolaan habitat dengan nilai manfaat 0,280 dan nilai kerugian 0,311, (3) pengelolaan populasi ikan melalui pembenihan dan restoking dengan nilai manfaat 0,202 dan nilai kerugian 0,493.

2. Peraturan dari lembaga yang ada akan lebih bermanfaat dalam pengelolaan dan pelestarian ikan bilih, baik peraturan propinsi Sumatera Barat dengan bobot 0,030 dan peraturan kabupaten dengan bobot 0,019, dan akan lebih bermanfaat lagi dengan peraturan adat (Peraturan Nagari) dengan bobot 0,095.

3. Untuk melaksanakan pengelolaan ikan bilih di Danau Singkarak perlu di fasilitasi oleh pemerintah Propinsi Sumatera Barat, karena secara administrasi lokasi danau Danau Singkarak berada pada dua kabupaten (Kabupaten Solok dan kabupaten Tanah Datar). Peran Pemerintah Propinsi yang sangat penting adalah memfasilitasi pertemuanpertemuan antara pemerintah nagari pada dua kabupaten tersebut dan memotivasi untuk membuat Peraturan Nagari untuk pengelolaan ikan bilih di Danau Singkarak karena Hukum adat lebih ditaati oleh masyarakat dan nelayan dibandingkan dengan Peraturan Daerah, 
baik Peraturan Daerah Propinsi maupun Peraturan Daerah Kabupaten.

\section{UCAPAN TERIMA KASIH}

Penulis menyampaikan ucapan terima kasih kepada Direktur Penelitian dan Pengabdian Kepada Masyarakat Ditjen Pendidikan Tinggi yang telah membiayai penelitian ini melalui skim penelitian Strategis Nasional Tahun 2010 dan 2011 dan artikel ini merupakan sebagian dari penelitian dengan judul "Kajian Konservasi : Tampilan Reproduksi, Domestikasi Plasma Nutfah Ikan Bilih Endemik dan Pengelolaannya Berbasis Masyarakat Lokal di Danau Singkarak".

\section{DAFTAR PUSTAKA}

Amis. M.A; M. Rouget; M. Lotter; J. Day. 2009. Integrating freshwater and terrestrial priorities in conservation planning. Biological Conservation.142: 2217-2226.

Kartamihardja, E.S. 2009. Pengelolaan sumberdaya ikan bilih (Mystacoleucus padangensis Blkr) Introduksi di Danau Toba, Sumatera Utara. Jurnal Kebijakan Perikanan Indonesia. 1 (2) : 87- 97.

Kartamihardja, E.S; K. Purnomo dan C.Umar. 2009. Sumber daya ikan perairan umum daratan di IndonesiaTerabaikan. Jurnal Kebijakan Perikanan Indonesia. 1 (1) : 1 - 15.

Krismono dan E.S. Kartamihardja. 2010. Pengelolaan sumber daya ikan di Danau Limboto, Gorontalo. Jurnal Kebijakan Perikanan Indonesia. 2 (1) : 27-41.

Kottelat, M., A.J. Whitten, with S.N. Kartikasari and S. Wirjoatmodjo. 1993. Freshwater Fishes of Western Indonesia and Sulawesi. Periplus Edition (HK), Jakarta.

Nasution, Z dan M.T.D. Sunarno. 2009. Pengembangan model pengelolaan suaka perikanan di perairan umum daratan berbasis ko manajemen. Jurnal Kebijakan Perikanan Indonesia. 1 (1) : 17-29.

Syandri, H 1996. Aspek reproduksi ikan bilih (Mystacoleucus padangensis Blkr) dan kemungkinan pembenihannya di Danau Singkarak. Disertasi Program Pascasarjana IPB Bogor.

Syandri, H2004. Pengelolaan sumberdaya perikanan perairan umum.Unri Prees.

Syandri.H; Y. Basri; N. Aryani dan Azrita. 2008. Kanjian kandungan nutrisi telur ikan bilih (Mystacoleucus padangensis Blkr) dari limbah hasil penangkapan nelayan di Danau Singkarak. Jurnal Perikanan dan Kelautan. 13 (1) : 118126.

Syandri, H. 2008. Ancaman terhadap plasma nutfah ikan Bilih (Mystacoleucus padangensis Blkr) dan upaya pelestariannya di Danau Singkarak. Orasi Ilmiah pada upacara pengukuhan Guru Besar Tetap Fakultas Perikanan dan IImu Kelautan Universitas Bung Hatta Padang. Bung Hatta University Press.

Syandri, H. 2011. Kadar nutrisi limbah telur ikan bilih (Mystacoleucus padangensis Blkr) sebagai sumber ransum pakan. Jurnal Akuakultur Indonesia. 10 (1) : 7480.

Utomo, A.D; Asyari dan S. Nurdawati. 2001. Peranan suaka perikanan dalam peningkatan produksi dan pelestarian sumberdaya perikanan perairan umum 
J. Kebijak. Perikan. Ind. Vol.3 No. 2 Nopember 2011 : 135-144

(Studi kasus di suaka perikanan Suak Budaya, Lubuk Lampam, Kab. Ogan Komering Ilir, Sumatera Selatan Jurnal Penelitian Perikanan Indonesia. 7 (1) : 1-9.
Weber, M and L.F de Beaufort. 1916. The fishes of the Indo-Australian Archipelago Volume III. Brill Leiden. 